\title{
THE WORLD NEEDS MORE ROD MACDONALD: THE POTENTIAL OF BIg IDEAS
}

\author{
KIM BROOKS*
}

In this article, the author makes the case for thinking boldly and experimentally about the possibilities for legal education and law schools and urges us to embrace the potential for big ideas. She illustrates this approach through the lens of admissions, curriculum, and research. Within each of those aspects of legal education, the article suggests some guidelines that might be used to evaluate reform proposals and proposes one major change to spur reflection.
Dans cet article, l'autrice établit le bien-fondé d'une réflexion audacieuse et empirique sur les possibilités de formation juridique et les écoles de droit; elle nous incite à saisir les grandes idées. Elle illustre cette approche à partir des admissions, du programme et de la recherche. Pour chacun de ces aspects de la formation juridique, l'autrice considère des lignes directrices pouvant servir à évaluer les réformes proposées et suggère un changement majeur dans le but de stimuler la réflexion.

\section{TABLE OF CONTENTS}

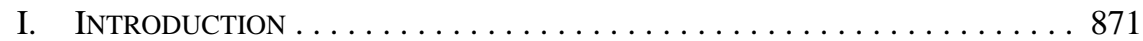

II. A CHALLENGING CONTEXT . . . . . . . . . . . . . . . . . . . . 873

III. In PuRsuit of Big Projects . . . . . . . . . . . . . . . . . . . . . 877

A. LAW SCHOOL ADMISSIONS ARE No LONGER THE BARRIER

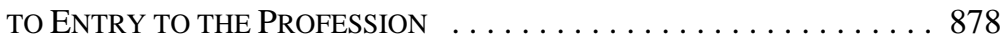

B. Curriculum MeEtings Could Be

More LiKe Convocation SPEECHES . . . . . . . . . . . . . . . 881

C. FOUR ESPRESSOS LATER AND I DO NOT WANT

TO BE WONDERING WHAT THE Point Is . . . . . . . . . . . . . 887

IV. The Obligation to Create Opportunities . . . . . . . . . . . . . . . 889

\section{INTRODUCTION}

Rod Macdonald has the perfect office at McGill: room 301 of 3674 Peel Street. It is in an old house. The dark wood interior feels like it remembers the trees it came from. When you walk up the stairs to Rod's office, and there are only stairs because the building is not wheelchair accessible, your left hand is drawn to the top of the newel post. You pause. This building seems like the kind of place where you could think big thoughts, if big thoughts were an option given your genetic and social educational endowments.

The rumour is that the house was once an enormous one-family home that was separated into two living spaces so that sisters could live together. It seems fitting that Rod finds his

Kim Brooks is the Weldon Professor of Law and Dean of the Schulich School of Law. With thanks to the participants at The Future of Law School Conference in celebration of the University of Alberta's Faculty of Law's centennial (September 2013) and to Constance Backhouse, Gillian Calder, Robert Leckey, Rod Macdonald, Moira McConnell, Shannon O’Byrne, Susan Sterett, and Sheila Wildeman for thoughtful comments on an earlier draft. I am indebted to the Social Sciences and Humanities Research Council of Canada for their support through the standard research grant program and, as always, to my colleagues at the Schulich School of Law for the many lessons they've taught me over the last four years. Thanks to Dawson McKay for his research assistance and Eric Adams for his patience and organizational talent. The magnificent Rod Macdonald passed away on 13 June 2014, after this article was completed. It is fitting, nevertheless, that this portion of the article is written in the present tense. After all, Rod will remain forever living in our collective legal imaginary. 
work home in this house, given his contributions to the way we think about interdependent relationships in law. ${ }^{1}$

Like most languishing university buildings that do not receive the benefit of what we so gently call "deferred maintenance work,” Rod's office has seen better days. Nevertheless, it is spectacular. It faces east, which must be fine for Rod because he is an early morning man, often in his office by 4:00 a.m. It has a turret window and a partially separated reading space. The walls are lined with bookshelves that look like they should be more securely attached.

When you walk into the room, Rod is often sitting in his chair, leaning in toward the monitor of his desktop computer, peering into the screen, face fixed in a slight scowl. When he turns toward you his face lights up. He grins. He insists that you sit down, flapping one of his seemingly endless arms in the general direction of the seating space to your right. More often than not he will stay sitting in his chair, return to scowling at his computer, and type furiously for a few more minutes to finish his thought. I use that time to flop down on his three-panel couch. When I wait for him, lying on the couch, arms crossed behind my head, staring at the ceiling, I wonder what it is that he thinks about all the time.

Eventually Rod will extract himself from his computer. He will wander over to the space where I am stretched out and sit across from me. He reminds me of a cat - not a docile, relaxed cat, but a tentative, slightly anxious cat, ever contemplating departure. What I have learned is that if you wait for Rod to say something, he will eventually erupt with something completely unexpected.

One day while I was lying there staring at the ceiling he announced: "I think we should teach all of first year through the lens of some regular object. Cars. Forget obligations and property. Imagine that we taught all of first year through something rooted in everyday life. Something that centred the real people for whom law is made.”

Imagine teaching all of first year as though human beings mattered most. What would that look like? The idea was so outrageous that I laughed. More than that, imagine teaching at a law school that had already made massive, fundamental change to the curriculum, and being willing to think about another way of re-visioning it, yet again, from the ground up.

We did not pursue the idea for long, however. I was likely in his office for some practical advice about where to submit something for publication or to kick around some bit of administrivia. But that conversation, and so many of the conversations I have had with Rod, stays with me. What I wish most for the future of legal education is that we could have more conversations in the vein of Rod and fewer conversations in the vein of whether a particular course, just to illustrate, should find itself in the first or the second year mandatory program.

See e.g. Law Commission of Canada, Beyond Conjugality: Recognizing and Supporting Close Personal Adult Relationships (Ottawa: Minister of Public Works and Government Services, 2001), in which Rod's influence is unmistakable. 


\section{A Challenging Context}

Before the 1970s there was a trickle of research on the state of the practice of law and the interaction between that practice and legal education. Between the 1970s and a few years ago, that literature grew incrementally in scope and depth. In the last five years, certainly since 2007's Carnegie report, ${ }^{2}$ and the 2008 economic crisis, the literature has exploded, with Canada, the United States, Australia, and the United Kingdom producing myriad dense reports on the state of the union of legal education. ${ }^{3}$ There is a wealth of material available and this is not the place to reiterate it in any detail.

What has emerged from this recent explosion of research is a sense that we are in a period of unfamiliar, rapid change. Over the last two decades the legal community has observed the massification of university education, including, in some jurisdictions, of legal education; ${ }^{4}$ witnessed a steady increase in student debt due to high tuition fees at both the undergraduate and law school stages; ${ }^{5}$ been engaged in changes to the design of the articling process; ${ }^{6}$ and taught a small portion of the ever increasing body of case law, regulation, and administrative practices in law school. We have fretted over the exorbitant cost of legal services; ${ }^{7}$ documented the continued exit of women from private practice; ${ }^{8}$ studied the high rates of depression and substance abuse among practicing lawyers; ${ }^{9}$ heard judges and others rail

2 William M Sullivan et al, Educating Lawyers: Preparation for the Profession of Law (San Francisco: Jossey-Bass, 2007).

See e.g. Task Force on the Canadian Common Law Degree, Final Report, October 2009 (Federation of Law Societies of Canada, 2009), online: Federation of Law Societies <http://www.flsc.ca/_documents/ Common-Law-Degree-Report-C(1).pdf $>$; American Bar Association Task Force on the Future of Legal Education, Draft Report and Recommendations (20 September 2013), online: American Bar Association <http://www.americanbar.org/content/dam/aba/administrative/professional_responsibility/ taskforcecomments/task_force_on_legaleducation_draft_report_september2013.authcheckdam.pdf $>$ [ABA, Draft Report]; Christopher Roper \& Council of Australian Law Deans Standing Committee on Standards and Accreditation, Standards for Australian Law Schools: Final Report (March 2008), online: Council of Australian Law Deans <http://www.cald.asn.au/docs/Roper_Report.pdf >; Legal Education and Training Review, Setting Standards: The Future of Legal Education Services and Training Regulation in England and Wales (June 2013), online: Legal Education and Training Review $<$ http://letr.org.uk/wp-content/uploads/ LETR-Report.pdf> [Legal Education and Training Reviw].

$4 \quad$ See e.g. Léo Charbonneau, “University Enrolment Continues to Climb in Canada” (29 October 2010), online: University Affairs <http://www.universityaffairs.ca/university-enrolment-continues-to-climb-incanada.aspx>.

5 See University tuition fees, 2013/2014,(Statistics Canada, 12 September 2013), online: Statistics Canada <http://www.statcan.gc.ca/daily-quotidien/130912/dq130912b-eng.pdf>; Sarah Rankin, "Today’s law grad: Six figures in debt and heading to Bay Street,” The Globe and Mail (2 April 2013), online: The Globe and Mail <http://www.theglobeandmail.com/news/national/education/todays-law-grad-sixfigures-in-debt-and-heading-to-bay-street/article10565699/>; Susan Goldberg, "Wealthy and Wise," online: Canadian Bar Association <https://www.cba.org/CBA/national/Students/Student01.aspx>. See Law Society of Upper Canada Articling Task Force, Pathways to the Profession: A Roadmap for the Reform of Lawyer Licensing in Ontario (25 October 2012), online: Law Society of Upper Canada <http://www.lsuc.on.ca/WorkArea/DownloadAsset.aspx?id=2147489848>.

7 See e.g. Lance Finch, “Access to Justice: The Elephant in the Room,” (Address delivered to the Canada Bar Association - BC Branch, 20 November 2010), online: The Courts of British Columbia <http:// www.courts.gov.bc.ca/Court_of_Appeal/about_the_court_of_appeal/speeches/CBA\%20Scottsdale\%20Final\%20Nov\%2022.pdf $>$.

$8 \quad$ See e.g. Final Report: Retention of Women in Private Practice Working Group (Law Society of Upper Canada, 22 May 2008), online: Law Society of Upper Canada <http://www.lsuc.on.ca/media/conv may08_retention_of_women.pdf>; Julius Melnitzer, "Women still leaving law at higher rate than men," Financial Post (26 April 2013), online: Financial Post <http://business.financialpost.com/2013/04/26/ women-still-leaving-law-at-higher-rate-than-men/>.

9 See e.g. "Addiction and Psychiatric Impairment of Lawyers and Judges,” online: Legal Profession Assistance Conference <http://www.lpac.ca/main/Courses_01/alcohol_03.aspx>; "Depression and Suicide Among Lawyers,” online: Legal Profession Assistance Conference <http://www.lpac.ca/main/ Courses_01/depression_02.aspx>. 
about the high numbers of self-represented litigants; ${ }^{10}$ seen diminishing government funding for legal work, including cuts to legal aid, ${ }^{11}$ and more recently, reductions in positions for lawyers at Justice and other government departments; ${ }^{12}$ and wailed over evidence that much of the population remains un- or under-served. ${ }^{13}$ We have witnessed the potential of new technologies to displace the traditional delivery of legal services; ${ }^{14}$ moved toward an increasingly deregulated market; ${ }^{15}$ facilitated greater jurisdictional mobility for lawyers; ${ }^{16}$ seen the disaggregation of legal work products and the potential for outsourcing of work to entirely different parts of the world; ${ }^{17}$ and recognized a trend toward colonization and worse, conformity in the legal profession. ${ }^{18}$ We doubt the long-term viability of our legal business models, including billing practices. ${ }^{19}$

These realities have caused a resurgence of interest in legal education, which is seen as a potential solution to some of these challenges, or at least an institutional home for concerns about the practice of law to be downloaded. It has been some time since legal education

See e.g. Family Justice Working Group of the Action Committee on Access to Justice in Civil and Family Matters, Meaningful Change for Family Justice: Beyond Wise Words (April 2013), online: West Coast LEAF < http://www.westcoastleaf.org/userfiles/file/FJWG\%20report\%20Meaningful\%20Change \%20Consultation\%20Jan\%202013.pdf>; Nicholas Bala \& Rachel Birnbaum, "The rise of the selfrepresented litigant and the challenges for family lawyers” The Family Way (October 2012), online: CBA <http://www. cba.org/CBA/sections_family/newsletters2012/self-representation.aspx >; Trevor CW Farrow et al, Addressing the Needs of Self-Represented Litigants in the Canadian Justice System (Association of Canadian Court Administrators, 27 March 2012), online: Canadian Forum on Civil Justice <http://www.cfcj-fcjc.org/sites/default/files/docs/2013/Addressing\%20the\%20Needs\%20of\%20 SRLs\%20ACCA\%20White\%20Paper\%20March\%202012\%20Final\%20Revised\%20Version.pdf>. See e.g. "Legal aid cuts could jam B.C. courts," CBC News (1 April 2009), online: CBC <http://www. cbc.ca/news/canada/british-columbia/legal-aid-cuts-could-jam-b-c-courts-1.800832>.

12 See e.g. Luis Millan, "Government Lawyers Buckling Under Workloads," The Lawyers Weekly (28 September 2012), online: The Lawyers Weekly <http://www.lawyersweekly.ca/index.php?section= article\&articleid $=1749>$.

13 See e.g. Access to Civil \& Family Justice: A Roadmap for Change (Ottawa: Action Committee on Access to Justice in Civil and Family Matters, October 2013), online: Canadian Forum on Civil Justice <http://www.cfcj-fcjc.org/sites/default/files/docs/2013/AC_Report_English_Final.pdf>; Warren K Winkler, “Access to Justice: Remarks" (30 April 2008), online: Ontario Courts <http://www.ontario courts.ca/coa/en/ps/speeches/accessjustice.htm>.

14 See e.g. John Markoff, “Armies of Expensive Lawyers, Replaced by Cheaper Software,” The New York Times (4 March 2011), online: The New York Times < http://www.nytimes.com/2011/03/05/science/05 legal.html?pagewanted=all\&_r=0>; Christopher Mims, "Replacing Personal Injury Lawyers With the Web,” MIT Technology Review (23 June 2011), online: MIT Technology Review <http://www. technologyreview.com/view/424460/replacing-personal-injury-lawyers-with-the-web/>; Jordan Weissmann, "iLawyer: What Happens When Computers Replace Attorneys?” The Atlantic (19 June 2012), online: The Atlantic <http://www.theatlantic.com/business/archive/2012/06/ilawyer-whathappens-when-computers-replace-attorneys/258688/>.

15 See e.g. Jane Croft, "Deregulation to shake up legal market,” Financial Times (12 February 2012), online: Financial Times <http://www.ft.com/cms/s/0/fcb5cc1e-541c-11e1-bacb-00144feabdc0.html\# axzz2wY9ROjyE>.

16 See e.g. Law Society of Upper Canada, Inter-Jurisdictional Mobility Committee, November 22, 2001: Report to Convocation (Law Society of Upper Canada, 2001), online: Law Society of Upper Canada $<$ http://www.lsuc.on.ca/media/convnov_interjuris.pdf>; “"Mobility within Canada,” online: Law Society of British Columbia <https://www.lawsociety.bc.ca/page.cfm?cid=215\&t=Mobility-within-Canada $>$.

17 See e.g. Matthew Wocks, "Legal process outsourcing grows by leaps and bounds," Financial Post (17 April 2013), online: Financial Post <http://business.financialpost.com/2013/04/17/legal-processoutsourcing-grows-by-leaps-and-bounds/>; Jeff Gray, "Bay Street's big legal firms turn to outsourcing," The Globe and Mail (26 September 2012), online: The Globe and Mail <http://www.theglobeandmail. com/report-on-business/industry-news/the-law-page/bay-streets-big-legal-firms-turn-to-out sourcing/article4570690/>.

18 See Roderick A Macdonald \& Thomas B McMorrow, “Decolonizing Law School” (2014) 51:4 Alta L Rev 717.

19 See "Law Firms: A Less Gilded Future" The Economist (5 May 2011), online: The Economist <http:// www.economist.com/node/18651114>. 
made news and the pages of The New York Times on a regular basis. ${ }^{20}$ The book industry has been kept afloat in no small part by the pandemic of books reminding us that the end of legal education, the practice of law, and life as we know it is nigh. ${ }^{21}$ The number and volume of conferences, workshops, task forces, and studies undertaken in Canada, the US, Australia, and the UK in the last five years easily dwarf everything undertaken on the topic in the last century.

In the face of mounting evidence that the legal landscape is changing rapidly, the question remains - how must law schools respond? The American Bar Association Task Force on the Future of Legal Education released a draft report in September $2013 .^{22}$ I disagree with most of the report, but the ABA did identify one of the major impediments to responding to challenges like the ones identified above: the culture of resistance to change in law schools (and the legal profession). As asserted in the Draft Report, "[t]he culture of law schools is at the root of many aspects of current conditions. It is a culture of customs and practices that developed when decision-making involved consideration of modest changes that could be

See e.g. Ethan Bronner, “To Place Graduates, Law Schools Are Opening Firms,” The New York Times (7 March 2013), online: The New York Times <http://www.nytimes.com/2013/03/08/education/lawschools-look-to-medical-education-model.html?pagewanted=all >; Ethan Bronner, "A Call for Drastic Changes in Educating New Lawyers," The New York Times (10 February 2013), online: The New York Times <http://www.nytimes.com/2013/02/11/us/lawyers-call-for-drastic-change-in-educating-newlawyers.html>; John J Farmer, “To Practice Law, Apprentice First,” The New York Times (17 February 2013), online: The New York Times <http://www.nytimes.com/2013/02/18/opinion/to-practice-lawapprentice-first.html>; Daniel B Rodriguez \& Samuel Estreicher, "Make Law Schools Earn a Third Year,” The New York Times (17 January 2013), online: The New York Times <http://www.nytimes. com/2013/01/18/opinion/practicing-law-should-not-mean-living-in-bankruptcy.html>; Victor Fleischer, "The Shift Toward Law School Specialization,” The New York Times (25 October 2012), online: The New York Times <http://dealbook.nytimes.com/2012/10/25/the-shift-toward-law-school-specializ ation/>; Tamar Lewin, “Law School Plans to Offer Web Courses for Master's," The New York Times (8 May 2012), online: The New York Times <http://www.nytimes.com/2012/05/09/education/lawschool-plans-to-offer-web-courses-for-masters.html >; Peter Lattman, "N.Y.U. Law Plans Overhaul of Students' Third Year," The New York Times (16 October 2012), online: The New York Times <http://dealbook.nytimes.com/2012/10/16/n-y-u-law-plans-overhaul-of-students-third-year/?_php=true \&_type=blogs\&_r=0>; David Segal, "Law School Economics: Ka-Ching!,” The New York Times (16 July 2011), online: The New York Times <http://www.nytimes.com/2011/07/17/business/law-schooleconomics-job-market-weakens-tuition-rises.html?pagewanted=all>; David Segal, "Is Law School a Losing Game?” The New York Times (8 January 2011), online: The New York Times <http://www. nytimes.com/2011/01/09/business/09law.html?pagewanted=all>; Andrew Ross Sorkin, "Big Steps Into Uncertain Times," The New York Times (24 September 2012), online: The New York Times <http://dealbook.nytimes.com/2012/09/24/big-law-steps-into-uncertain-times/>; Brian Z Tamanaha, "How to Make Law School Affordable,” The New York Times (31 May 2012), online: The New York Times <http://www.nytimes.com/2012/06/01/opinion/how-to-make-law-school-affordable.html?gwh= A81325165287FEF06A7DBA5E8ABAA762\&gwt=pay>; Clifford Winston, "Are Law Schools and Bar Exams Necessary?” The New York Times (24 October 2011), online: The New York Times <http:// www.nytimes.com/2011/10/25/opinion/are-law-schools-and-bar-exams-necessary.html?gwh= B331D69FD05B369C08D3C1C8F66AFC31\&gwt=pay>; David Segal, "For Law Schools, a Price to Play the A.B.A's Way,” The New York Times (17 December 2011), online: The New York Times <http://www.nytimes.com/2011/12/18/business/for-law-schools-a-price-to-play-the-abas-way.html? gwh=B95B841ACEADA6DD5FE704DEA49FC363\&gwt=pay>; David Segal, "What They Don't Teach Law Students: Lawyering,” The New York Times (19 November 2011), online: The New York Times <http://www.nytimes.com/2011/11/20/business/after-law-school-associates-learn-to-be-lawyers. html ?pagewanted=all\&gwh=23AD11EDA70DF17B8888D374BFFE7638\&gwt=pay>.

21 See e.g. Richard Susskind, The Future of Law: Facing the Challenges of Information Technology (Oxford: Oxford University Press, 1996); Thomas D Morgan, The Vanishing American Lawyer (Oxford: Oxford University Press, 2010); Judith Finer Freedman, Cracking the Code: Unlocking the Potential of Future Leaders in the Legal Profession (Eagan, MN: Thomson Reuters, 2010); Mitchell Kowalski, Avoiding Extinction: Reimagining Legal Services for the 21st Century (Chicago: American Bar Association, 2012); Paul Maharg, Transforming Legal Education: Learning and Teaching the Law in the Early Twenty-first Century (Aldershot, UK: Ashgate, 2007); Brian Z Tamanaha, Failing Law Schools (Chicago: University of Chicago Press, 2012). ABA, Draft Report, supra note 3. 
implemented over relatively long time frames. Today's challenges require a much stronger culture of innovation."23

The description of the culture of resistance at law schools resonates with me. Law schools are slow to change. As faculty members, we guard our autonomy carefully. We are reluctant to admit when we are wrong or that we could do better. Quixotically, we are anxious about whether we are teaching our classes or writing scholarship as well as we could be. Our anxiety often paralyzes us, leading us to adopt more conservative approaches rather than the needed riskier efforts. Scholarship is hard work that requires time and internal motivation. We worry that spending time on other projects will inevitably lead to less focus on the part of our job (scholarship) that for some of us is the hardest. And, we are trained incrementalists. There are myriad other reasons why we resist change, and my purpose here is simply to nod at the possible explanations for the culture of resistance to change in law schools.

In what remains of this article, I provide a tour of some of the renovations we might consider. I do so under the familiar heads of the provision of legal education — admissions, curriculum, and research. The list of topics is restricted only by the length of the article, and could have included the role of the library (and librarians), tuition policy, pedagogy, and recruitment of faculty and staff, among other vitally important areas of the life of a law school.

Although the following pages explore possible changes to legal education, the purpose of this exercise is not to generate a definitive road map for the direction of legal education. In fact, the more I learn about legal education and the practice of law, the less sure I am that I have any firm or fixed idea about the right or best way forward. Instead, I hope that this article will spark discussion about possibilities and options. This might seem, at first glance, like a cop-out: I should embrace and advocate directions. To the contrary, in this article I want to encourage us, as legal educators, to think boldly and experimentally about the possibilities for legal education and law schools and to be unabashed in asking "why" about aspects of our approach that are so familiar as to seem beyond review. The aspiration of this orientation is that going forward we may espouse and try on some less comfortable clothing.

As a final point, I note that I set out some of the context above not because I think it matters, but because I think it might be motivating for others. My view is that we should be pervasively engaged in conversations about big ideas and modest renovations to the design of legal education: that part of the joy of being an academic is spending some time each year thinking about what we might do differently, perhaps better. To that end, the context provided by the sky-is-falling litany above is irrelevant. A better contextual list, which would more aptly frame a conversation about new directions for law schools and legal education would be thicker. It might explore which segments of the labour market have become more mobile, the effect of rising income and wealth inequality on society, the evidence about the effectiveness of corporate mergers, the implications of food scarcity, and so on. In short, we might focus our context-setting attentions on current human realities and public policy dilemmas, assessing how those are shifting, and think about how to renovate our approach 
to legal education in light of those changes. Such a context would motivate us to respond proactively because we care about how our graduates will engage with these realities, not because we are reactively trying to catch up with stories about changes to the world of legal practice.

\section{In Pursuit of Big Projects}

So, if it is not already clear, given today's context of rapid change, unique public policy challenges, and other shifting human realities our students will face upon graduation, I am in favour of big projects. Canadian law schools are surprisingly homogeneous, made all the more so by the efforts of the Federation of Canadian Law Societies. ${ }^{24}$ In each of the sections that follow, I do three things: (1) provide some brief context for an aspect of law school design and highlight, as inspiration, a moment or two where I think that aspect was transformed in the past; (2) suggest some guidelines to evaluate the appropriateness of any proposed big ideas; and (3) propose one possible, major change that responds to that context and aligns with those guidelines.

There is no magic to the proposals. On a different writing day, I might have worked on others. For example, I am not adverse to a two-year Juris Doctor (J.D.) program, particularly if the law school is not otherwise inclined to distinguish what students are intended to learn in their third year from what they learned in their first and second years, and especially in the light of rising tuition costs. I am interested in projects focused on articulating explicit learning objectives for a legal education and allowing students to graduate when they demonstrate achievement of those objectives (taking a two, three, or four year program, depending on the particular student). There seems to be merit to developing new streams of legal education that would grant a different degree to students who primarily want to offer legal information to other professionals (for example, doctors, engineers, or social workers) or who want to develop products like software, contracts, or information management systems, that would be used more generally by the public (so called "legal-information engineers”). ${ }^{25}$ There are myriad admissions-based projects worth talking about. Just to be provocative, we could debate the advantages of setting minimum thresholds for admission and drawing students' names from a hat (as opposed to rank ordering them by grades, Law School Admission Test (LSAT) scores, and some other variable or two) or submitting names to a computer program that would admit students not as individuals, but as a diverse entering class with the broadest possible range of life experiences, ideological perspectives, racial identities, geographic affinities, and so on. American initiatives that enable students to participate in a for-credit law school firm with the main object of improving access to justice for lower and middle income people should be discussed. All of these ideas are worth exploring. These are not the ideas I chose to explore in this article. The point of this modest article is to demonstrate that there are big ideas to be pursued and to urge us to consider that the timing might be appropriate for some more dramatic innovation, or at least renovation, in the design of Canadian law schools. Hopefully these ideas fit well with the spirit of Rod

24 See e.g. Task Force on the Canadian Common Law Degree, supra note 3.

25 See e.g. Larry E Ribstein, “Practicing Theory: Legal Education for the Twenty-First Century” (2011) 96:5 Iowa L Rev 1649. 
Macdonald, who has throughout his career so generously shared his big ideas with his colleagues, in his scholarship, and in his work in aid of development of robust public policy.

\section{A. LAw School Admissions ARE No Longer the BARRIER TO ENTRY TO THE PROFESSION}

It is hard to imagine anything appealing about moving to Keystone (now Bretton), Alberta in 1911. One imagines that the farmers would have faced harsh winters, limited food supplies, and widely dispersed populations. Yet this is the place where John and Stella King settled after emigrating from their home in Oklahoma. As an African American family, they were entering an environment hostile not only to human existence, but also to their race. By 1912, surprised, I suspect, to find African Americans responding to their settlement call, the Canadian government took steps to discourage African Americans from immigrating. But by then, key historical moments for the University of Alberta's Faculty of Law, and the practice of law in Canada, had been set in motion.

After moving to Calgary in 1919, John took up working as a sleeping car porter and Stella as a seamstress. The couple gave birth to Violet King in 1929. From at least her high school days Violet knew that she wanted to be a lawyer. Following high school and a one-year business program, Violet began studying at the University of Alberta in 1948. Her first year in the law school was 1950, and she graduated as the first African Canadian student to do so in 1953. She articled with Edward J. McCormick, Q.C., a criminal lawyer in Calgary, working on five murder trials that year, and was called to the bar in 1954. Violet King became the first female African Canadian lawyer in Canadian history.

According to the limited accounts of her life, Violet practiced criminal law for a couple of years and then left practice to join the federal Department of Citizenship and Immigration in 1956. She worked for some time in Ottawa. By 1963, she had moved to the US where she held a number of senior management positions with the YMCA. She died of cancer in 1981 or 1982, without announcement. I am grateful that Rachel Bailie rehabilitated something of Violet's story in the pages of the Canadian Journal of Women and the Law in 2012. ${ }^{26}$

The 1950s marked the beginning of a time of transition for admissions programs across the country that was completed by the mid-1970s. Although women, and African Canadians, had entered many of the country's law schools almost half a century earlier, it was not until some time after Violet's arrival that women began entering law school in large numbers. The sex diversity of the law school class, alongside the move to adjudicate admissions files by more objective measures, like undergraduate grades and LSAT scores, came in the early 1970s. ${ }^{27}$ Those changes reflect watershed moments in Canadian law school admissions policy. It has been some time, though, since admissions practices at Canadian law schools found themselves in a transformative moment. ${ }^{28}$

Rachel K Bailie, “Minority of One: Violet King’s Entry to the Legal Profession” (2012) 24:2 CJWL 301. William P LaPiana, "A History of the Law School Admission Council and the LSAT" (Keynote Address delivered at the LSAC Annual Meeting, 1998), online: LSAC <http://www.lsac.org/docs/defaultsource/publications-(lsac-resources)/history-lsac-lsat.pdf>.

28 See e.g. Larry Chartrand et al, "Law Students, Law Schools, and Their Graduates" (2001) 20 Windsor YB Access Just 211; Dawna Tong \& W Wesley Pue, "The Best and the Brightest?: Canadian Law School Admissions” (1999) 37:4 Osgoode Hall LJ 843. 
This might, however, be such a moment. Since at least the mid-1970s, law school admissions at common law schools in Canada have been and continue to be highly selective. Sixteen common law schools admit approximately 4,500 students per year. ${ }^{29}$ Almost every student admitted to law school passes the program. Almost every student who graduates from a Canadian law school and writes the bar exams of a province passes those exams. Almost every student who passes the bar exam secures an articling position and is admitted to practice. Once a student is in law school, it is a pretty safe bet that he or she will become a lawyer. Therefore, for 40 years, the barrier to entry to the legal profession has been admission into a Canadian law school.

But the past several years have seen marked changes to applications for admission to the practice of law. Two new law schools have joined the cluster of common law schools, total enrolment at the original 16 schools has crept up, and our National Committee on Accreditation has seen exponential increases in applications to practice law in Canada year over year (in 2012-2013 alone 730 certificates were issued, which makes the National Committee on Accreditation the largest Canadian law school with the fastest increasing enrolment). ${ }^{30}$ There are no signs that the pace of applications from foreign-trained lawyers and foreign-trained students to practice law in Canada is going to decline, nor is there any evidence that the number of students attending law school at Canadian institutions will diminish.

For the last 40 years, legal regulatory bodies have been able to rely, in essence, on high admission standards, as measured by grades and LSAT scores, as the barrier to entry to the practice of law. Given the intelligence of the entering pool, regulators presumably have not had to worry much about how capable practicing lawyers are and they have not instigated regular assessments of lawyer competence. However, now that the barrier to entry to the practice of law in Canada is changing rapidly, these regulatory bodies simply cannot continue to rely on admission standards as an effective gatekeeper to the legal profession.

For law schools, this moment, with the growing number of Canadian students pursuing legal education abroad, and essentially sidestepping the historic barrier to access professional practice in Canada, presents the kind of moment that the influx of a more diverse group of students might have presented in Violet King's day. Fortunately, law schools are not constrained by the regulatory pressures of law societies. Although we have functioned as the de facto regulator of admission to the practice of law, we no longer informally need to serve that function. Given the increasing numbers of ways students can access legal information, be legally educated, and arrive at the doors of the regulator, law schools should feel liberated from the sense that we need to serve as the informal barrier to entry. We cannot serve as the backstop to the testing of competence by regulatory bodies and we cannot be expected to restrict the number of students to the number of lawyers who may be able to be placed in

29 As compiled by the Law School Admission Council: "Geographic Guide to Canadian Law Schools," online: LSAC <http://www.lsac.org/jd/choosing-a-law-school/canadian/geographic-guide>.

See Federation of Law Societies of Canada, "Publications and Resources," online: Federation of Law Societies of Canada <http:// www.flsc.ca/en/resources/> (reports date back to 1998. The number of National Committee on Accreditation (NCA) certificates granted has increased from 153 in 2003-2004 to 466 in 2010-2011 and 730 in 2012-2013. The numbers of certificates granted each year is provided by the NCA on request). 
articles or other entry-level legal positions. Experimentation and innovation in admissions is possible.

Since law schools are not beholden to regulatory bodies to be the de facto gatekeepers of the profession and are free to innovate their admission policies, this raises the issue of exactly how such innovation should take place. By what guidelines should Canadian law schools design admission processes? First, to the extent that a law school uses measures to predict law school success, they should be free from bias. In some instances, the low cost of using LSAT scores as a predictor may be too overwhelming for a school to resist. In those cases, though, statistically reliable compensatory curving should be developed in an effort to better compare racialized students (for example) with other applicants. ${ }^{31}$

Second, each law school should articulate clear objectives for their admissions policies. Are we trying to attract the students who will perform best in our programs, or students who are likely, based on their past experiences or characteristics, to make significant contributions to the legal profession and civil society? Do we seek a diverse group of students geographically, racially, ideologically, in terms of their articulated aspirations? Should we admit students with a demonstrated commitment to solving public policy and other human problems? Whatever our objectives, they should be informed by the aspirations we have, as public institutions, for the difference we hope our students will make.

Third, law schools should delineate skills, talents, and attitudes that we want students to have on admissions and distinguish those from skills, talents, and attitudes we intend to develop when students are engaged in study at our schools, appreciating that in many cases we may want to see the kernels of a particular attitudinal stance, for example, with the aspiration of supporting its flourishing. In other words, this is not about list A, completely distinct from list B, but rather a way of thinking about what students learn in law school and how it builds on their prior knowledge and ways of being.

Here is one suggestion for law schools to consider in renovating admissions: start admitting students based on their likelihood of success in the profession and as engaged jurists. Admissions processes have evolved in response, largely, to predictors of law school success. However, other professions, like medicine, have made some headway in redesigning their admissions practices to align them with predictors of career success. That work has been made harder in law because of the dearth of research on what makes a good lawyer (assuming that one is selecting students who may wish to practice law) and on what might predict what makes a good lawyer.

Fortunately, research is finally being done, and progress is being made. For example, in 2011, Marjorie Shulz and Sheldon Zedeck published a wonderful piece, "Predicting Lawyer Effectiveness: Broadening the Basis for Law School Admissions Decisions.”32 In that piece,

31 There is a rich literature on the racial and ethnic bias of the LSAT. See e.g. William C Kidder, "Does the LSAT Mirror or Magnify Racial and Ethnic Differences in Educational Attainment?: A Study of Equally Achieving ‘Elite’ College Students” (2001) 89:4 Cal L Rev 1055.

32 Marjorie M Shultz \& Sheldon Zedeck, "Predicting Lawyer Effectiveness: Broadening the Basis for Law School Admissions Decisions” (2011) 36:3 Law \& Soc Inquiry 620 [Shultz \& Zedeck, "Predicting Lawyer Effectiveness"]. See also Marjorie M Shultz \& Sheldon Zedeck, Final Report: Identification, Development, and Validation of Predictors for Successful Lawyering (September 2008), online: 
which builds on at least 10 years of work together, they document 26 factors as important for lawyer effectiveness: analysis and reasoning, creativity/innovation, problem-solving, practice judgment, researching the law, fact-finding, questioning and interviewing, influencing and advocating, writing, speaking, listening, strategic planning, organizing and managing one's own work, organizing and managing others, negotiation skills, ability to see the world through the eyes of others, networking and business development, providing advice and counsel and building relationships with clients, developing relationships within the legal profession, evaluation and development and mentoring, passion and engagement, diligence, integrity and honesty, stress management, community involvement and service, and selfdevelopment. ${ }^{33}$ These factors strike me, without testing, as desired characteristics in most of the kinds of careers our students will pursue, not only in traditional legal practice settings. In other words, they may not be characteristics of effectiveness for astronauts or comedians, but they are likely also characteristics of effectiveness for political analysts, politicians, legal journalists, justice advocates, and business people. In short, the kind of professional careers our students are likely to pursue if they do not pursue traditional legal practices.

Shulz and Zedeck found that two of the tests they developed to measure those skills a biographical information data test and a situational judgment test — correlated with 24 and 23 of the 26 lawyer effectiveness factors, respectively. (Other tests they used correlated to some, but not nearly as many, of the factors that influence lawyer effectiveness.) LSAT scores and undergraduate grades were found to correlate to very few of the 26 factors. Additionally, the tests for lawyer effectiveness showed few racial or gender differences. In other words, these tests move away from some of the well-documented bias of the LSAT for racialized students.

One big project for admissions would be to abandon the historic measures of law school success in the design of legal education and, at least for some students, move toward new measures of career effectiveness. Imagine a school that took seriously the project of admitting those students likely to make the most important contributions to the field of law, in whatever positions, and took less seriously the project of admitting students who would perform well on end-of-term exams.

\section{B. Curriculum Meetings Could Be MORE LIKE CONVOCATION SPEECHES}

Convocation speeches call to our greatest selves. When the speakers are good, they invoke the role of the graduate in changing the world, they question what graduates will do next and who they will be, they urge graduates to resist conventionalism and to challenge orthodoxies, they call to our sense of enchantment, and they leave us inspired to be our best versions of ourselves. Although the curriculum shapes the students who will become those graduates by essentially supporting their readiness for the grand project of living a fully engaged life, curriculum meetings and curricular design rarely suffer from an overabundance of ambition.

Berkeley Law <http://www.law.berkeley.edu/files/LSACREPORTfinal-12.pdf>; Marjorie M Shultz \& Sheldon Zedeck, “Admission to Law School: New Measures” (2012) 47:1 Educational Psychologist 51; Kristen Holmquist et al, "Measuring Merit: The Shultz-Zedeck Research on Law School Admissions" (2104) 63:4 J of Legal Educ 565. 
The Canadian law school curriculum, at least in terms of the labels we place on the courses we make mandatory, has changed little over time. Take, for example, the curriculum offered in Alberta in 1912-1913: "property, commercial law, equity, criminal law, practice and procedure, constitutional law, contracts, torts, evidence and wills." ${ }^{34}$ Many of these courses remain compulsory and, excepting wills, the rest are taken by the vast majority of students.

The last major change in the design of legal education in Canada occurred in the 1960s and 1970s. ${ }^{35}$ That era saw a growth in interest in the interaction between law and society and greater recognition for the potential of interdisciplinarity. There was a move toward fewer mandatory courses and more, specialized, upper-year options, as well as the addition of legal research and writing courses. ${ }^{36}$ These changes were enabled, in part, by the rapid expansion in class sizes in most already existing Canadian law schools and the rapid growth in the total number of full-time faculty members.

It might be liberating to think of curriculum reform as a socially complex problem, of the sort identified in the UK's Legal Education and Training Review. ${ }^{37}$ The UK review identifies characteristics of socially complex problems - there is no definitive definition of the problem; the problem is intractable; the information needed to make sense of the problem is often ill-defined, changing, and may be difficult to put into use; there are multiple stakeholders, limited consensus on which stakeholders are legitimate, and different stakeholders are likely to have different criteria of success; and every attempt at a solution matters significantly.

It is a mistake to try to resolve socially complex problems with one-time, straightforward solutions. Instead, as recommended by the Legal Education and Training Review, it makes sense to recognize that there are no right or wrong answers (necessarily), only better or worse ones, and that continuing engagement will undoubtedly be necessary.

There are myriad resources for those interested in a list of propositions that might guide the design of curricular reform. ${ }^{38}$ In this article, I suggest that curriculum design should build on nine fundamental guidelines. First, it should privilege training in skills that require systematic training, not learning that might be undertaken in a "crash course" in response to a particular problem. ${ }^{39}$ Second, it should facilitate a common understanding of some baseline cases and statutes thought to be generally known by lawyers in the jurisdiction. Third, it

See Peter M Sibenik, “Doorkeepers: Legal Education in the Territories and Alberta, 1885-1928” (1990) 13:1 Dal JL 419 at 446 . If a student wanted to receive the LLB he or she additionally had to take jurisprudence, history, and additional constitutional law. 35 See the review by Rod Macdonald, "Legal Education on the Threshold of the 1980's: Whatever
Happened to the Great Ideas of the 60s" (1979-1980) 44:1 Sask L Rev 39; Roderick A Macdonald, "Curricular Development in the 1980s: A Perspective" (1982) 32:4 J Legal Educ 569; HW Arthurs, "Paradoxes of Canadian Legal Education" (1977) 3:3 Dal LJ 639 [Arthurs, "Paradoxes"].

36 See e.g. John Willis, A History of Dalhousie Law School (Toronto: University of Toronto Press, 1979); Arthurs, "Paradoxes," ibid at 644-59.

Legal Education and Training Review, supra note 3 at 5.

See e.g. Harry Arthurs, “'Valour Rather Than Prudence’: Hard Times and Hard Choices for Canada’s Legal Academy” (2013) 76:1 Sask L Rev 73 at 83-84.

$39 \quad$ See Bruce Ackerman, "Why legal education should last for three years," The Washington Post (6 September 2013), online: The Washington Post <http://www.washingtonpost.com/opinions/why-legaleducation-should-last-for-three-years/2013/09/06/55d80c06-1025-11e3-8cdd-bcdc09410972_ story.html>. 
should build on the requirement that students obtain an undergraduate degree (or we should abandon the requirement). Fourth, it should build on student skills progressively through their three years. ${ }^{40}$ Fifth, it should reflect the fact that many students will become lawyers, but a sizable number of them will not find themselves in private practice by midway through their careers, and a significant number will not practice law for more than a few years. ${ }^{41}$ The primary objective, then, of legal education should be to support students in becoming broadminded public policy thinkers - experts in the use of legal materials. To this end, I side with the third of Harry Arthurs' views of what law schools should be, namely, that we "should play a leading role in the transformation of legal knowledge, legal practice, and the legal system." 42 Sixth, the curriculum should inspire creativity, curiosity, innovation, and collaboration. Perhaps one of the reasons why law and legal practice have been so slow to adapt to the challenges of access to justice and the antiquated business model of many law firms is that law schools failed to provide students with enough creative spark to do anything different. Seventh, it should build strong commitment to service in the public interest. The practice of law is a regulatory monopoly and one of the trade-offs for that arrangement, enshrined in the legislative frameworks of provincial regulatory bodies, requires that lawyers be regulated in the public interest. ${ }^{43}$ Eighth, the curriculum should facilitate integration between and among areas of law and situate them around the human beings who inevitably act at the centre of legal disputes. Ninth, the curriculum should focus on refining and understanding how legal problems are defined, and on creative and wide-range approaches to identifying alternative solutions. ${ }^{44}$

What follows is a proposal for curricular reform that applies the guidelines set out above, in the context of the Schulich School of Law at Dalhousie. I think that a workable curriculum for a law school should turn on a variety of factors specific to that law school: what kind of students it attracts; how do, and how can, its faculty members work together; what, if any, areas of specialization does the law school care about; how well integrated is the law school into other areas of inquiry at the university; how willing are faculty members to commit time to student learning; and so on. An approach to curriculum that tries to build on the strength of the existing faculty members and students would inevitably result in a more heterogeneous approach to legal education in Canada. It would likely also result in greater change over time, as faculties adjust their curricula to changing faculty and student interests, demographics, and talents. In other words, I suspect that the homogeneous approach to the curricular design of legal education across the country likely does not draw out the real strengths and talents of some faculties and students. The only real advantage is that students are not likely to be interested in attending a school outside their home jurisdiction to obtain a different curricular offering. There is nothing "right" about the proposed curriculum below. I am proposing it

40 See Nancy B Rapoport, “Rethinking U.S. Legal Education: No More 'Same Old, Same Old”” (2013) 45:4 Conn L Rev 1409.

41 Fiona M Kay, Stacey Alarie \& Jones Adjei, Leaving Law and Barriers to Re-entry: A Study of Departures from and Re-entries to Private Practice (Law Society of Upper Canada, April 2013), online: Law Society of Upper Canada <http://www.lsuc.on.ca/WorkArea/DownloadAsset.aspx?id=2147 494539>.

42 See HW Arthurs, “The Future of Law School: Three Visions and a Prediction” (2014) 51:4 Alta L Rev 705.

$43 \quad$ See e.g. Legal Profession Act, SNS 2004, c 28; Nova Scotia Barristers' Society, "Regulations Made pursuant to Legal Profession Act, SNS 2004, c 28,” online: Nova Scotia Barristers' Society <http://www.nsbs.org/sites/default/files/cms/menu-pdf/currentregs.pdf>.

44 On this last guideline, I think I join with the position taken in Ian Holloway's article in this volume (Ian Holloway, “A Canadian Law School Curriculum for this Age” (2014) 51:4 Alta L Rev 787). 
simply to spark discussion. I do, however, think it could be implemented at the Schulich School of Law at Dalhousie given our student (approximately 165 students a year) and faculty (approximately 35 full-time faculty members, with the usual sabbatical leaves) complement.

\section{FIRST YEAR: MODERNIZATION AND ENGAGEMENT}

A revision of the first-year curriculum has two objectives: first, to modernize the curriculum by providing students with the opportunity to delve into some of the more specialized areas of law that build on the historic first-year building block courses; and second, to engage students better by enabling some choice and providing course offerings that allow students to connect with at least one or two of the topics that inspired them to come to law school in the first place.

In our first year at Schulich, we offer the traditional complement of courses - torts, property law, contracts, criminal law, legal research and writing, and public law (a course we added in the early 1980s). ${ }^{45}$ To modernize the first-year offerings, we could reduce the traditional courses from six to four credits. Students would write exams (or complete other summative assessments) in the traditional first-year courses in the last two weeks of January. This could be accomplished by extending the teaching term in first year for two weeks in December.

A new complement of courses would start the first week of February and run for eight weeks. Those courses would be worth two credits each. Students would be offered a choice between two courses that build upon and show more modern developments of the initial substantive courses. Summative assessments in those courses would take place or be due during the April exam period. To illustrate, torts might become a choice between health and environmental law, contracts might become a choice between legal theories and international law, property law might become a choice between judicial remedies and intellectual property, and public law might become a choice between legislation and dispute resolution. Criminal law might become two credits of professional responsibility for all students. Additional writing and research support might be provided by offering one of the four credit courses in a small group and by offering legal research and writing as a three credit course, focused mainly in the first term.

\section{SECOND Year, FirSt Term: BuILDing Substantive Matrices}

The first term of second year would be designed to provide students with a broad, admittedly shallow, matrix for the substantive framework of the range of subjects that a school believes provides important building blocks. Twelve intensive courses would be offered in one week blocks, taught Monday to Thursday for four hours a day. There would be only one section of each intensive block. In other words, the block would be taught to the year as a whole. This form of teaching achieves a few objectives. First, it reduces the 
teaching resources dedicated to the first term of second year (enabling greater resources to be provided to the first-year small groups and to the third-year small group workshops). Second, it changes the learning format for students for at least one term of their six-term legal education.

For Schulich, one way to generate a list of intensive, matrix-building courses would be to draw on the courses for which we offer four credits (rather than three) and to include the courses that are mandatory as a result of the Federation of Law Societies requirements. The list of courses that results from applying that approach has the benefit of providing a good mix of courses in the areas historically considered to be part of public and private law, procedural and substantive.

Courses would be grouped into clusters of four. Students would write an exam at the end of each cluster. Students would be required to take three of the four subjects taught in each cluster of four. This would enable time for reflection and study, and also accommodation of some of the life pressures confronted by second-year students, like job interviews. Each cluster would result in the receipt of four credits for the student, and require 48 hours of class time out of a possible 64 hours. Students could elect to take all four subjects in a cluster, and would then receive an additional credit for that cluster, reducing their course load in the second term of second year.

Just to illustrate, using the list of Schulich courses that are currently worth four credits and the courses required by the Federation:

Foundations 1: Evidence, Tax, Aboriginal, Business Associations

Foundations 2: Charter, Family, Administrative, Civil Procedure

Foundations 3: Federalism, Trusts, Criminal Procedure, Conflicts

At the same time as they are enrolled in these three Foundations courses, students would be engaged in a three credit advanced legal research and writing course that would be focused on oral advocacy and legislative research.

\section{Third Year, First Term: Human AND Public Policy Problems}

The third year presents the biggest challenge to legal education: providing students with sufficient support for their post-graduation endeavours. How do we make sure, given the rapidly changing world our students confront, that our students graduate with the substantive knowledge, skills, and attitudes that will stand them in good stead over the longer course of their careers as jurists?

Third year might be focused on breaking down the traditional course silos and rooting the student experience in the problems faced by real people. We could put life events front and centre - death, birth, family, food, education, health, sex, relationships, bodies, ownership, work, housing, money, violence, animals, and resources, for example.

The matrix-building second-year design frees up the human resources required to offer a third year, full-term, 15 credit, legal problems class. It would be a required course that builds 
student problem-solving skills in a way that reflects the human and public policy problems law confronts most directly. It would provide an intensive experience, enhance legal writing, research, and procedural skills, and require students to work in teams and independently.

The legal problems course would be taught in small groups of 20 students, with four instructors (three faculty members and one practitioner) assigned to team teach each class. The faculty members teaching each legal problems class would have a mix of substantive area expertise, so that each cluster reflects a diversity of areas and skills. To illustrate, the full-time faculty members assigned to teach the course may be experts in torts, property law, administrative law, tax, intellectual property, evidence, contracts, and constitutional law. That section would then be enriched by a practitioner who would bring expertise in procedure. $^{46}$

Students would know the main substantive areas of the cluster when they sign up for their legal problems class. That way they could choose substantive areas that aligned with their general areas of interest. Ideally, the subjects would be so diverse that all sections of the course would have substantive areas of interest to each student who enrolled in that section. One credit of the course would be allocated to professional responsibility, and that credit would be integrated into the assignments and materials over the term.

Each week the students in the course would receive an assignment. They might meet with one or more of the professors at a regular time on Monday to discuss the assignment for the week and to lay some of the groundwork for the substantive and procedural issues raised by the assignment. Students would then work on the assignment individually or in teams, as required by the assignment. They could regularly meet with the professors to discuss hurdles and challenges. The assignment would be due on Friday.

Every section of the legal problems course would start with the same fact pattern. A family with a small business would likely provide enough richness to create the range of problems required to run the duration of the course. In week one, one of the family members might be convicted of a crime and the students would be required, by the end of the week, to address sentencing. In week two, the family might find themselves confronting a human rights claim because someone in their business alleges that the business does not offer appropriate accommodation for a worker's disability. Week three might see the need to reorganize the company to issue a new class of shares. Week four might require a motion to family court be made to adjust a child custody order. Week five might require preparing a brief for government to support or resist a particular legislative change, and so on. Each student would receive an individual or team grade on each assessment each week with feedback provided in a timely fashion. 


\title{
4. SECOND AND THIRD YEAR: SECOND TERM
}

The second and third year second term would look much like it has since the mid-1970s: students would be permitted to enroll in a variety of optional seminar and lecture courses.

\section{FOUR ESPRESSOS LATER AND I DO NOT WANT TO BE Wondering What THE Point Is}

\begin{abstract}
So much for Objective Journalism. Don't bother to look for it here - not under any byline of mine; or anyone else I can think of. With the possible exception of things like box scores, race results, and stock market tabulations, there is no such thing as Objective Journalism. The phrase itself is a pompous contradiction in terms. ${ }^{47}$
\end{abstract}

I first encountered Hunter S. Thompson when I was in high school and picked up a copy of Fear and Loathing: On the Campaign Trail ' $72 .^{48}$ That book was a weird place to cut into Thompson, but he was a weird guy, so in hindsight, it was fitting. The book is a collection of articles, originally from Rolling Stone, on the Democratic Party primaries in 1972 focused especially on George McGovern. The writing was mesmerizing in the way that I later came to expect from the work of talented new journalists like Hunter Thompson, Truman Capote, Norman Mailer, and Joan Didion. I wondered why journalists would ever want to write in any other way. The author was located in the text. The subjectivity of the journalist was explicitly acknowledged. The reporting was intensive and lively. The topics seemed less superficial than the daily news stories I was otherwise reading in the Toronto Star.

If one way of assessing whether something is worth reading is to ask whether the author and the material discussed in the work are lively, engaged, meaningful, substantive, and immersed, then the Arthurs Report of 1983 was, and is, worth the read. ${ }^{49}$ Its publication was a clarion call for reflection on the state of legal research in this country. The report concluded that legal scholarship ought to be broadened to embrace a wider range of intellectual styles, graduate programs in law were suffering, there was over-concern with doctrinal work and under-concern with theoretical and fundamental research, legal scholars had failed to build important interdisciplinary bridges with other scholars in the academy, and legal scholarship was not well or much used. ${ }^{50}$ In many ways, Lee Epstein and Gary King's US piece, "The Rules of Inference,” had similar repercussions in the American context. ${ }^{51}$ Their paper, with its bold claim that "the current state of empirical legal scholarship is deeply flawed,"52 excited some in the legal academic world and infuriated others. "The Rules of Inference" generated a heightened discussion of the role of legal scholarship that has not, in my

\footnotetext{
$47 \quad$ Hunter S Thompson, Fear and Loathing: On the Campaign Trail '72 (New York: Grand Central Publishing, 1973) at 33.

48 Ibid.

49 Consultative Group on Research and Education in Law, Law and Learning: Report to the Social Sciences and Humanities Research Council of Canada (Ottawa: Social Sciences and Humanities Research Council of Canada, 1983) [Arthurs Report].

50 Ibid at $153-63$.

51 Lee Epstein \& Gary King, "The Rules of Inference” (2002) 69:1 U Chicago L Rev 1 [Epstein \& King "The Rules"]. See also their response to critics in the same volume: Lee Epstein \& Gary King, "A Reply” (2002) 69:1 U Chicago L Rev 191.

52 Epstein \& King “The Rules," ibid at 6 [emphasis omitted].
} 
experience, been generated since. The piece was featured in a number of academic settings, and it was the focus of a good part of the discussions at the 2002 Law and Society Association meetings.

Thompson and the new journalists changed the future of journalism. The Arthurs' Report and the Epstein and King piece call on legal scholars to do the same thing; to transform the way we engage with our scholarship. Instead of producing a radical departure from past practice, though, the Arthurs' Report has resulted in more incremental developments in legal scholarship along the lines that the report proposed. But the change has not been dramatic.

The scope and objectives for faculty scholarship should be left as wide as possible. As a result, I suggest only three guidelines. First, work should be peer reviewed. No one produces great work alone or in a vacuum. We all benefit from inviting focused, constructive engagement with our work. The peer review processes of law journals or granting agencies, for example, work well on this front. Even rigorous co-reading and review, for example, could fit within this broad guideline. The main point is that no one should write and then publish something without engaging with others.

Relatedly, my second point is that authors should seek to have their work used by others, and should read and engage with the work of others. The standard marker for the creation of this kind of community of scholars is citation counts. I think citation counts are not a bad marker of the dispersion and influence of our scholarship under the current model. ${ }^{53}$ If your work is not being cited, I think it is worth spending some time changing your dissemination (and possibly your own reading) practices. Scholarship - especially given that it is publicly funded — can and should be distinguished from journaling.

Finally, scholars should be bold. We need to engage deeply in the spirit of inquiry, and remain conscious that we are situated in public institutions. We should fiercely resist external commitments that might skew the arguments we advance. We should not shy away from criticism and scrutiny. The rationale, presumably, for so heavily subsidizing academic writing with public funds is that academics should be liberated to raise hard issues, even if they are unpopular or might fetter their chances of receiving otherwise lucrative remuneration. Our obligation to take seriously the public commitment to supporting our work should be paramount over all other commitments.

I think it may be time for a new journalism moment in legal scholarship. ${ }^{54}$ Legal scholarship could be transformed by a deliberate focus on extraordinary writing. A good deal

53 This is not to advocate for citation count as a metric, or certainly as the only metric, of scholarly contribution. In thinking about how to measure scholarly contribution, a pluralist approach, combining quantitative and qualitative approaches, would be ideal. A faculty could look at citation counts in various aggregators: downloads of open access materials, presentations of research results, research grants received, scholarly awards and recognitions, citations by courts, citations in government documents, media appearances, and publications by undergraduate and graduate students at the school. Faculties might also look to the research trajectory of scholars (do they build on their previous insights, are they intellectually engaged with each other and with those in their field) and to even more fundamental questions like, does the scholarship of the faculty reflect the broad spirit of inquiry?

54 The argument in this part of the article is painfully short — a concession to word length. I hope to return to this question, of the direction of legal scholarship, in subsequent work. 
of legal scholarship is too long ${ }^{55}$ and involves reiterating arguments that have been made elsewhere. ${ }^{56}$ The audience is unclear. Footnotes are used too heavily. If we could accept that almost no idea is born without multiple parents, perhaps we could free ourselves from the need to cite every possible article that might ever have said something on the topic on which we are working. We might embrace as a fundamental requirement of legal scholarship that it be interesting to read. Imagine limiting yourself to say, 20 footnotes and 6,000 words. Imagine asking yourself before publishing something: Do I know who I want to read this paper and do I have a dissemination plan? Will the reader need four espressos to get through it? Is the argument obscure and buried within a lengthy review of the state of the union? Have I obtained constructive and thoughtful feedback from at least five people with a stake in the argument? In short, we might take more seriously the project of good writing. ${ }^{57}$

\section{The Obligation to Create Opportunities}

Despite the pressures of the university, academic life presents myriad opportunities. In his convocation speech upon accepting an honourary degree from York University in 2011, Rod Macdonald remarked, "[t]he measure of a person is not where you start, or even where you end up. It is found in what you make of your life, what you do with the opportunities you've been given, and those you have striven to create for yourself." ${ }^{28}$ I hope that we will not be contented with accepting things as they are, in the face of significant evidence that what we do now is not what we might best do, but rather that we will make more of the opportunities we have been given and that we will strive to create unexpected openings for ourselves. Sometimes those openings come in the form of big ideas. L Rev 1.

56 For a critical review of the state of legal research in law faculties in 2003 (and there is no reason to think it has changed much in ten years) see Roderick A Macdonald, "Still ‘Law’ and Still ‘Learning’?” (2003) 18:1 CJLS 5 at 10-14

57 See e.g. Christopher Grey \& Amanda Sinclair, “Writing Differently” (2006) 13:3 Organization 443.

$58 \quad$ See e.g. "Roderick Macdonald accepts an Honorary Doctorate” (25 July 2011) (YouTube video), online: YouTube <http://www.youtube.com/watch?v=5HWxpo_HIf0>. 